\title{
Field resistance and molecular detection of the orange rust resistance gene linked to G1 marker in Brazilian cultivars of sugarcane
}

\author{
Ícaro Fier $^{1} \mathbb{D}$, Thiago Willian Almeida Balsalobre ${ }^{1} \mathbb{D}$, Roberto Giacomini Chapola ${ }^{1} \mathbb{D}$, Hermann Paulo Hoffmann $^{1}\left(\mathbb{D}\right.$, Monalisa Sampaio Carneiro $^{1}(\mathbb{D}$
}

${ }^{1}$ Universidade Federal de São Carlos, Centro de Ciências Agrárias, Departamento de Biotecnologia e Produção Vegetal e Animal, Rodovia Anhanguera, km 174 - SP-330, CEP 13.600-970 - Araras-São Paulo, Brazil.

Corresponding author: Monalisa Sampaio Carneiro (monalisa@ufscar.br)

Data de chegada: 26/03/2019. Aceito para publicação em: 19/12/2019.

$10.1590 / 0100-5405 / 221803$

\begin{abstract}
Fier, I.; Balsalobre, T.W.A.; Chapola, R.G. Hoffmann, H.P.; Carneiro, M.S.. Field resistance and molecular detection of the orange rust resistance gene linked to G1 marker in Brazilian cultivars of sugarcane. Summa Phytopathologica, v.46, n.2, p.92-97, 2020.

Sugarcane (Saccharum spp.), an important crop for tropical and subtropical countries, is used in the production of sugar and biofuel. Orange rust, a disease caused by the fungus Puccinia kuehnii, can reduce the yield and harm the sugarcane industry. Molecular markers linked to resistance genes can help breeding programs confirm introgression of favorable alleles, find new resistance sources and release new cultivars that have durable resistance. In the current study, the aims were (i) to evaluate in the field the resistance to orange rust of 24 Brazilian commercial cultivars; (ii) to assess the frequency of the allele at G1 marker locus in the set of cultivars, and (iii) to

study the usefulness of G1 marker to predict the resistant phenotype and its potential for marker assisted selection. A diagrammatic scale, which ranged from 1 (plants without symptoms) to 9 (highly susceptible plants), was used to determine the disease severity. Considering resistant cultivars those with mean severity up to 3, G1 marker efficiency in predicting the resistant phenotype was $71.43 \%$. In addition, there was a reduction of $35 \%$ in the overall mean severity when G1 marker was present. G1 marker is an important molecular tool that can be used by breeding programs in the search for sugarcane cultivars resistant to orange rust.
\end{abstract}

Keywords: Puccinia kuehnii, Sacharum spp., breeding, disease

\section{RESUMO}

Fier, I.; Balsalobre, T.W.A.; Chapola, R.G. Hoffmann, H.P.; Carneiro, M.S.. Resistência no campo e detecção molecular do gene de resistência à ferrugem alaranjada associado ao marcador G1 em cultivares brasileiros de cana-de açúcar. Summa Phytopathologica, v.46, n.2, p.92-97, 2020.

A cana-de-açúcar (Saccharum spp.) é uma cultura importante para países tropicais e subtropicais, utilizada principalmente para produção de açúcar e biocombustível. A ferrugem alranjada, doença causada pelo fungo Puccinia kuehnii, pode reduzir a produtividade e prejudicar toda a cadeia industrial. Marcadores moleculares associados com genes de resistência podem auxiliar programas de melhoramento a confirmar introgressão de alelos favoráveis, encontrar novas fontes de resistência e liberar novas cultivares com resistência durável. No presente estudo os objetivos foram: (i) avaliar em campo a resistência a ferrugem alaranjada de 24 cultivares comerciais brasileiras; (ii) acessar a frequência do alelo do marcador G1 no conjunto de cultivares; e (iii) avaliar a utilidade do marcador G1 na predição de fenótipo resistente e seu pontencial na seleção assistida por marcadores. Uma escala diagramática, a qual varia de 1 (plantas sem sintomas) até 9 (plantas altamente suscetíveis), foi utilizada para determinar a severidade da doença. Quando consideramos como cultivares resistentes àquelas que tiveram média de severidade até 3 , a eficiência do marcador G1 na predição do fenótipo resistente foi de $71.43 \%$. Em adição, houve uma redução de $35 \%$ na média geral de severidade quando o marcador G1 foi presente. O marcador G1 é uma importante ferrramenta molecular que pode ser usada por programas de melhoramento na busca por cultivares de cana-de-açúcar resistentes a ferrugem alaranjada.

Palavras-chave: Puccinia kuehnii, Sacharum spp., melhoramento, doença

Sugarcane orange rust is caused by the biotrophic fungal pathogen Puccinia kuehnii, an economically important pathogen worldwide. Since its first report causing endemic disease in Australia in 2000, a new race of the pathogen devastated the highperforming sugarcane cultivar Q124, and caused Aus\$150-210 million in yield losses (1). In susceptible cultivars, the pathogen has been responsible for important yield losses reaching up to $50 \%$ cane yield $(2,3,4)$. In 2007, the disease was discovered in the United States (5) and rapidly spread to other countries of America, such as Guatemala (6), Mexico, El Salvador, Panama (7), Costa Rica and Nicaragua (8). It was also detected in Colombia (9) and Ecuador (10). In Brazil, orange rust was first reported in 2009 and is currently present in all cultivated areas of the country (11). Brazil is the world leader in sugarcane production, presenting approximately nine million cultivated hectares and productivity was estimated at 73.22 ton. $^{-1} a^{-1}$ in the $2018 / 19$ crop season $(12,13)$.

Typical symptoms of orange rust are pustules (uredinial lesions) on the underside of the leaves showing cinnamon to orange coloration (14). In severe infections, coalescing pustules can cause premature death of leaf tissue (15). This disease causes reduction in the photosynthetic rate and carbon capture, due to the formation of pustules, thus reducing the growth and tillering of the plant $(16,17,18,19)$. Spores of the orange rust pathogen are extremely numerous on infected leaves of susceptible plants and are easily dispersed by the wind and rain (15). Chemical control of orange rust with the application of fungicides can be used in the 
short term in cases of severe pathogen infection $(1,7)$. However, the use of resistant cultivars is the most effective control method and does not burden farmers with additional charges to maintain crop productivity (14).

Despite the relevance to the sugarcane industry, few studies have been conducted to identify genetic variability and presence of races for P. kuehnii. Moreira et al. (20) showed that P. kuehnii isolates did not compose different races, but the isolate from one site (Araras, São Paulo State, Brazil) was the most aggressive race. There are also few studies to understand the genetic inheritance of this disease.

Diagrammatic scales developed for brown rust assessment (21, 22) were used to verify the incidence and severity of orange rust (19). More recent methods have been proposed specifically for orange rust, both for artificial inoculation (23) and for natural field incidence $(18,24)$. Klosowski et al. (25), using the diagrammatic scale developed by Klosowski et al. (24) and considering resistant the asymptomatic genotypes, studied the inheritance of orange rust resistance and results suggested that resistance is controlled by a major gene in conjunction with several other genes of minor effects. The results also suggested that resistant genotypes can be obtained from the crossing between two susceptible genotypes. In another study, using the diagrammatic scale developed by Sood et al. (23) and considering resistant the genotypes with scores between 0 and 2 (presence of lesions but without sporulation), Yang et al. (26) developed a molecular marker associated with a resistance gene, called G1, from QTL mapping of F1 population derived from a cross between CP95-1039 (resistant) and CP881762 (susceptible). G1 molecular marker was capable of predicting $65.8 \%$ resistant phenotypes in the mapping population. G1 marker genotyping is easily performed through agarose gel with a fragment of approximately 950 base pairs.

To develop resistant cultivars, trials for phenotypic evaluation and identification of genetic sources of resistance should be conducted. In this same line, the molecular markers associated with genes responsible for resistance to orange rust can be used in the screening of resistant clones in early stages of breeding programs. In addition, they may indicate potential parents for future crosses and help establish resistance alleles. As is the case for brown rust, in which molecular markers associated with the Brul resistance gene have been used by breeding programs to increase the level of resistance to this disease $(17,27,28)$, development of molecular markers associated with resistance to orange rust is expected to also contribute to changing the current scenario and accelerating the availability of resistant cultivars.

The aims of the present study were (i) to evaluate the field resistance to orange rust of 24 Brazilian commercial cultivars of sugarcane; (ii) to assess the frequency of the allele at G1 marker locus in these cultivars, and (iii) to study the usefulness of G1 marker to predict resistant phenotype and its potential application in marker assisted selection (MAS). This is the first report of the use of G1 molecular marker in Brazilian sugarcane germplasm.

\section{MATERIAL AND METHODS}

\section{Plant material}

Field evaluation and G1 marker analysis were carried out for 24 Brazilian cultivars of sugarcane (Table S1). These cultivars represent an important genetic background for Brazilian breeding programs, especially regarding two factors: i) they have been or are still among the most cultivated cultivars in the country (29) and; ii) they are used as main parents in Brazilian breeding programs.

\section{Severity of natural orange rust infection in the field}

All data of field assays were obtained under conditions of natural infection. The phenotypic response of cultivars to orange rust was based on historical data of several trials conducted between 2011 and 2018 (Table S1) at the Agricultural Sciences Center of the Federal University of São Carlos (UFSCar), located in Araras, São Paulo State, Brazil (22 21' 25" S; 47 23'03” W and average altitude of $611 \mathrm{~m}$ ). Araras Municipality is located in a region classified to have moderate to high risk of orange rust epidemics (30). The climate is classified as Cwa mesothermic (Köppen classification), showing hot and humid summers and dry winters. The annual average temperature in the experimental area is $21.5^{\circ} \mathrm{C}$, ranging from $17.9^{\circ} \mathrm{C}$ in the coldest month (July) to $24.2^{\circ} \mathrm{C}$ in the hottest month (February), and average annual precipitation is $1,435 \mathrm{~mm}$. Experimental design and assessment of orange rust resistance were described by Chapola et al. (19). Briefly, the trials were conducted in randomized complete block design with four replicates, and plots consisted of two rows of $2 \mathrm{~m}$ length spaced $1.4 \mathrm{~m}$ apart. The susceptible cultivar SP89-1115 was planted as border/spreader rows between replicates to increase the inoculum pressure within the experimental area. The disease severity was determined on the +3 leaf, in ten plants per replicate, by estimating the percentage of leaf area affected by symptoms based on the diagrammatic scale of Amorim et al. (22), in which a score of 1 indicates absence of sporulating pustules (uredospores), a score of 2 indicates very rare sporulating pustules and scores from 2 to 9 indicate increasing density of sporulating pustules. A mean value of disease severity was obtained for each cultivar considering all the performed observations. Based on mean disease severity, cultivars with scores of 1 to 3 were classified as resistant, cultivars with scores from 4 to 6 were classified as intermediate and cultivars with scores from 7 to 9 were classified as susceptible.

\section{G1 marker analysis}

Total genomic DNA samples were extracted from the 1+ internode (leaf primordia) of the 24 sugarcane cultivars, as proposed by Al-Janabi et al. (31). Samples were quantified with NanoDrop One equipment (Thermo Scientific) and stored at $-20^{\circ} \mathrm{C}$. PCR amplifications were performed in $20 \mu \mathrm{l}$ reaction containing $10 \mathrm{X}$ PCR buffer (10 mM Tris- $\mathrm{HCl}, 50 \mathrm{mM} \mathrm{KCl}$ ), $2.5 \mathrm{mM} \mathrm{MgCl}_{2}, 0.2$ $\mathrm{mM}$ each dNTP, $1 \mu \mathrm{M}$ each forward and reverse primer, $0.5 \mathrm{U}$ Taq DNA polymerase (Promega), $40 \mathrm{ng}$ template DNA and ultrapure water to complete volume. Touchdown PCR was performed, as proposed by Yang et al. (26). Briefly, after initial denaturation at $95^{\circ} \mathrm{C}$ for $5 \mathrm{~min}$, four steps were carry out: i) five cycles of $1 \mathrm{~min}$ denaturing at $96^{\circ} \mathrm{C}, 5 \mathrm{~min}$ annealing at $68^{\circ} \mathrm{C}$ with a decrease of $2{ }^{\circ} \mathrm{C}$ in each subsequent cycle, and 1 min extension at $72^{\circ} \mathrm{C}$; ii) five cycles of $1 \mathrm{~min}$ denaturing at $96^{\circ} \mathrm{C}, 2 \mathrm{~min}$ annealing at $58^{\circ} \mathrm{C}$ with a decrease of $2^{\circ} \mathrm{C}$ in each subsequent cycle, 1 min extension at $72^{\circ} \mathrm{C}$; iii) 25 cycles of 1 min denaturing at $96^{\circ} \mathrm{C}, 1$ min annealing at $50^{\circ} \mathrm{C}$ and $1 \mathrm{~min}$ extension at $72^{\circ} \mathrm{C}$; and iv) a final extension at $72^{\circ} \mathrm{C}$ for $5 \mathrm{~min}$. PCR products were run on $1 \%$ agarose gel in horizontal electrophoresis. Considering the genotyping results, the cultivars with presence of G1 maker, a fragment of approximately 
950 base pairs, were encoded with ' $\mathrm{P}$ ' and cultivars with absence of this fragment were encoded with ' $A$ '. Prediction of the resistant phenotype was obtained by dividing the number of both phenotypic and genotypic resistant cultivars by the number of genotypic resistant cultivars, and multiplying the result by 100 .

\section{RESULTS}

The results regarding orange rust mean severity, reaction to the disease and genotyping of G1 marker for each cultivar are summarized in Table 1. Orange rust mean severity, based on historical data, showed that $16(66.67 \%), 5(20.83 \%)$ and $3(12.50 \%)$ sugarcane cultivars can be grouped in resistant, intermediate and susceptible reaction classes, respectively.

Of the 24 evaluated cultivars, $14(58.33 \%)$ had the G1 marker and showed overall mean severity of 2.62. Four cultivars presenting G1 were asymptomatic (SP91-1049, SP80-3280, RB966928 and RB855536). On the other hand, G1 marker was also present in cultivars showing mean severity higher than 1 , which ranged from 1.35 (RB855453) to 7.44
(RB72454). Although susceptible to the disease, the cultivar RB72454 is one of the parents to the resistant cultivars RB855536 (SP70-1143 x RB72454), RB867515 (RB72454 x ?) and RB835054 (RB72454 x NA56-79), as well as to the intermediate cultivar RB855156 (RB72454 $x$ TUC71-7), all presenting G1 marker (Table 1).

Regarding resistant cultivars, those with mean severity scores between 1 and 3 had G1 marker efficiency in predicting resistant phenotype of $71.43 \%$ (Table 2). Such prediction of efficiency decreased to $28.57 \%$ and $57.14 \%$ when cultivars showing mean severity scores equal to 1 and 1 to 2 , respectively, were considered resistant (Table 2).

On the other hand, G1 marker was absent in ten cultivars (Table 1) which had overall mean severity of 3.55 . For these cultivars, mean severity scores were greater than 1, ranging from 1.19 (SP80-1842) to 7.56 (SP79-2233). G1 marker efficiency in predicting susceptible phenotype was $100 \%, 70 \%$ and $40 \%$ when cultivars showing mean severity scores greater than 1, 2 and 3, respectively, were considered susceptible (Table 2).

Considering the evaluated cultivars, there was a reduction of $35 \%$ in the overall mean severity when G1 marker was present, decreasing from 3.55 to 2.62 (Figure 1).

Table S1. Twenty-four Brazilian commercial cultivars of sugarcane evaluated for orange rust severity, their parental, growing area in hectares (ha) and number of field trials that participated between 2011 and 2018.

\begin{tabular}{|c|c|c|c|c|}
\hline Cultivar & Parental 1 & Parental 2 & Growing area $(\mathrm{ha})^{1}$ & Number of trials \\
\hline RB835054 & RB72454 & NA56-79 & 44,803 & 5 \\
\hline RB835486 & L60-14 & $?$ & 9,907 & 7 \\
\hline RB855035 & L60-14 & SP70-1284 & 15,893 & 5 \\
\hline RB855536 & SP70-1143 & RB72454 & 98,586 & 8 \\
\hline RB867515 & RB72454 & $?$ & 875,692 & 7 \\
\hline RB925211 & RB855206 & $?$ & 2,422 & 4 \\
\hline RB92579 & RB75126 & RB72199 & 284,713 & 11 \\
\hline RB975201 & RB855113 & $?$ & 35,519 & 4 \\
\hline RB975242 & F147 & $?$ & 10,838 & 4 \\
\hline RB975952 & RB835486 & RB825548 & 13,063 & 4 \\
\hline RB985476 & H53-3989 & RB855206 & 6,775 & 4 \\
\hline SP79-2233 & H56-2954 & $?$ & 0 & 4 \\
\hline SP80-1842 & SP71-1088 & H57-5028 & 56,589 & 9 \\
\hline SP80-3280 & SP71-1088 & H57-5028 & 50,262 & 4 \\
\hline SP81-3250 & SP71-1279 & CP70-1547 & 150,667 & 11 \\
\hline
\end{tabular}

${ }^{1}$ Growing area in hectares, concerning the states of São Paulo and Mato Grosso do Sul, according to 2018/19 varietal census (RIDESA, 2018). São Paulo and Mato Grosso do Sul accounted for 60\% Brazilian sugarcane production in 2018 (CONAB, 2018). 
Table 1. Groups of sugarcane cultivars according to the presence or absence of G1 molecular marker, orange rust mean severity ${ }^{1}$ and reaction to disease of each cultivar, and overall mean severity by groups of cultivars.

\begin{tabular}{|c|c|c|}
\hline Cultivars & Mean severity ${ }^{1}$ & Reaction to disease \\
\hline \multicolumn{3}{|l|}{ G1 Presence } \\
\hline SP91-1049 & 1.00 & Resistant \\
\hline SP80-3280 & 1.00 & Resistant \\
\hline RB966928 & 1.00 & Resistant \\
\hline RB855536 & 1.00 & Resistant \\
\hline RB855453 & 1.35 & Resistant \\
\hline RB867515 & 1.36 & Resistant \\
\hline RB835054 & 2.00 & Resistant \\
\hline RB965902 & 2.00 & Resistant \\
\hline RB935744 & 2.18 & Resistant \\
\hline RB855035 & 2.80 & Resistant \\
\hline RB92579 & 3.67 & Intermediate \\
\hline RB855156 & 4.08 & Intermediate \\
\hline RB925211 & 5.81 & Intermediate \\
\hline RB72454 & 7.44 & Susceptible \\
\hline Overall mean severity & 2.62 & \\
\hline \multicolumn{3}{|l|}{ G1 Absence } \\
\hline SP80-1842 & 1.19 & Resistant \\
\hline RB975242 & 1.83 & Resistant \\
\hline RB975201 & 2.00 & Resistant \\
\hline RB835486 & 2.14 & Resistant \\
\hline RB985476 & 2.16 & Resistant \\
\hline RB975952 & 2.33 & Resistant \\
\hline SP83-2847 & 3.35 & Intermediate \\
\hline SP81-3250 & 5.59 & Intermediate \\
\hline SP89-1115 & 7.37 & Susceptible \\
\hline SP79-2233 & 7.56 & Susceptible \\
\hline Overall mean severity & 3.55 & \\
\hline
\end{tabular}

${ }^{1}$ Orange rust mean severity was obtained from several field trials conducted between 2011 and 2018.

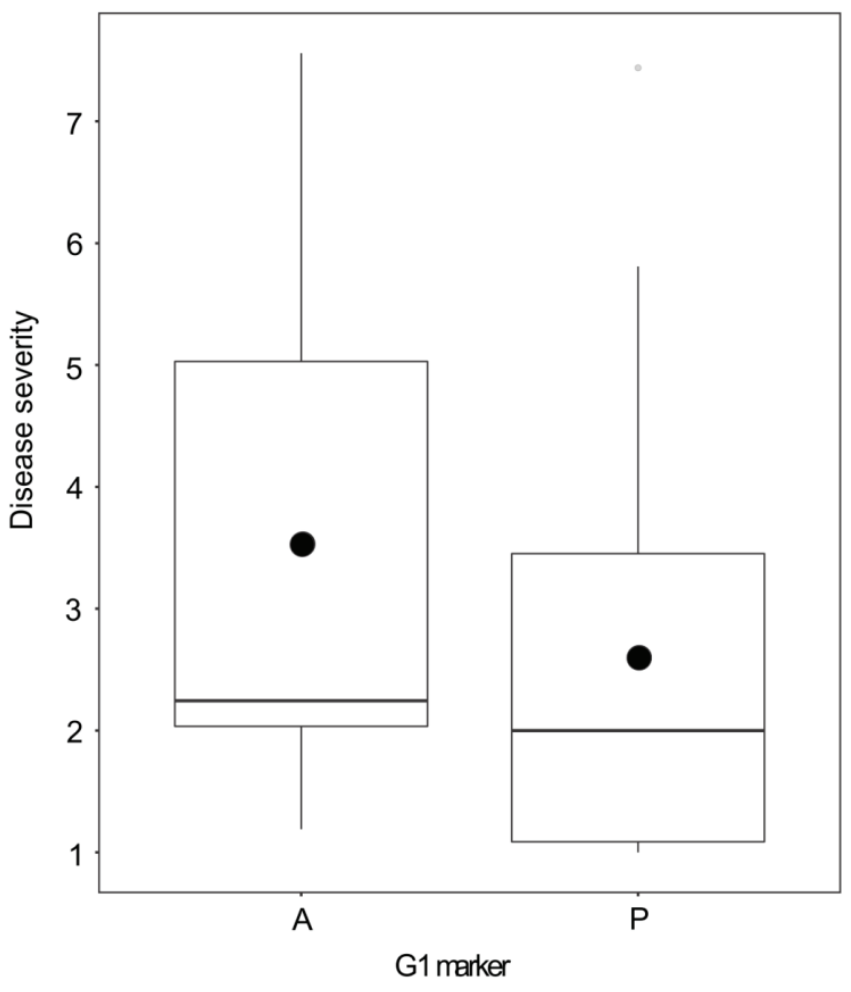

Figure 1. Boxplots of groups of sugarcane cultivars according to the presence (P) or absence (A) of G1 marker to orange rust severity. The black point indicates the overall mean severity of each group and the line inside boxplots indicates the median.

\section{DISCUSSION}

Sugarcane is one of the most important crops around the world, widely used for sugar and ethanol production $(12,32)$. However, diseases such as orange rust are related to yield reduction. Development of molecular tools could help find resistance sources and consequently contribute to the release of new cultivars with satisfactory resistance levels. In a recent study, Yang et al. (26) developed a molecular marker associated with a resistance gene to orange rust, called G1, which was evaluated in the present study for a set of sugarcane cultivars from Brazilian breeding programs.

The field trials conducted between 2011 and 2018 showed that $66.67 \%$ evaluated cultivars were resistant to orange rust, indicating that although this disease was recent in Brazil, some resistant cultivars were already available before the arrival of the pathogen. This was important to avoid great yield losses due to orange rust in the Brazilian growing

Table 2. Resistant and susceptible phenotype prediction in sugarcane cultivars, from G1 marker genotyping, considering three classes of resistant phenotypes, according to the diagrammatic scale used to evaluate orange rust severity: mean severity $=1$, mean severity $\leq 2$ and mean severity $\leq 3$.

\begin{tabular}{ccccccccc}
\hline $\begin{array}{c}\text { Classification } \\
\text { of resistant } \\
\text { phenotype }\end{array}$ & $\begin{array}{c}\text { Number of } \\
\text { resistant } \\
\text { cultivars } \\
\text { (mean) }\end{array}$ & $\begin{array}{c}\text { Number of } \\
\text { resistant } \\
\text { cultivars with }\end{array}$ & $\begin{array}{c}\text { Total of } \\
\text { cultivars } \\
\text { with G1 }\end{array}$ & $\begin{array}{c}\text { Prediction of } \\
\text { G1 marker } \\
\text { for resistant } \\
\text { phenotype }\end{array}$ & $\begin{array}{c}\text { Number of } \\
\text { susceptible } \\
\text { cultivars } \\
\text { (mean) }\end{array}$ & $\begin{array}{c}\text { Number of } \\
\text { susceptible } \\
\text { cultivars } \\
\text { without G1 }\end{array}$ & $\begin{array}{c}\text { Total of } \\
\text { cultivars } \\
\text { without } \\
\text { G1 }\end{array}$ & $\begin{array}{c}\text { Prediction of } \\
\text { G1 marker } \\
\text { for susceptible } \\
\text { phenotype }\end{array}$ \\
\hline Mean severity $=1$ & $04(1.00)$ & 04 & 14 & $28.57 \%$ & $20(3.41)$ & 10 & 10 & $100.00 \%$ \\
Mean severity $\leq 2$ & $11(1.21)$ & 08 & 14 & $57.14 \%$ & $13(4.34)$ & 07 & 10 & $70.00 \%$ \\
Mean severity $\leq 3$ & $16(1.71)$ & 10 & 14 & $71.43 \%$ & $08(5.60)$ & 04 & 10 & $40.00 \%$ \\
\hline
\end{tabular}


areas, allowing rapid substitution of susceptible cultivars. Nevertheless, the number of asymptomatic or resistant cultivars to orange rust is still small $(18,19,20)$, especially because the breeding programs did not practice selection against the disease until its emergence.

G1 molecular marker, associated with the resistance gene, was present in $58.33 \%$ evaluated Brazilian cultivars, showing $71.43 \%$ efficiency in predicting resistant phenotype when cultivars with mean severity scores up to 3 were considered resistant, according to the diagrammatic scale proposed by Amorim et al. (22). This result was slightly higher than that obtained by Yang et al. (26), who indicated $65.8 \%$ efficiency in predicting resistant phenotype for the F1 mapping population evaluated in their study. In addition, similar to that reported by Yang et al. (26), in the present study the presence of G1 marker reduced the overall mean severity by $35 \%$.

On the other hand, the disease severity evaluation methodology and the phenotypic classification into resistant and susceptible were different between the studies: Yang et al. (26) used a diagrammatic scale developed by Sood et al. (23), which ranged from 0 (plants without symptoms) to 4 (highly susceptible plants), to evaluate the disease severity after artificial inoculation and classified the genotypes of the F1 mapping population as resistant if their score was between 0 and 2 and as susceptible if their score was 3 and 4; in the present study, we used the diagrammatic scale by Amorim et al. (22), which ranged from 1 (plants without symptoms) to 9 (highly susceptible plants), to evaluate the disease severity under natural field conditions, and cultivars with scores above 3 were considered susceptible. Originally, the diagrammatic scale of Amorim et al. (22) was developed to evaluate brown rust severity. However, the differences between studies are mainly due to the type of test: artificial inoculation of the pathogen carried out by Yang et al. (26) and natural infection in the present study. Anyway, the resistance gene identified by G1 marker showed to be effective in decreasing the disease severity for both the biparental progeny (26) and the set of cultivars evaluated in the present study, which do not have the same pedigree. Thus, G1 marker demonstrates great potential to be used in MAS of orange rust resistance in sugarcane.

Moreira et al. (20) showed that P. kuehnii isolate from Araras Municipality, São Paulo State, Brazil, presented the greatest aggressiveness and, in the present study, ten cultivars with G1 marker showed mean severity above 1 (RB855453, RB867515, RB835054, RB965902, RB935744, RB855035, RB92579, RB855156, RB925211, RB72454), also suggesting that the pathogen has high aggressiveness and that the resistance gene associated with G1 marker could act together with other genes to cause the asymptomatic phenotypic effect. Similarly, Klosowski et al. (25) showed that resistance to orange rust is controlled by a major gene and several other accessory genes, indicating possible transgressive segregation.

Although there is still no evidence of different virulent races of $P$. kuehnii, Yang et al. (26) suggests that the resistance gene associated with G1 marker is responsible for durable resistance (horizontal resistance) rather than single race-specific resistance (vertical resistance). To demonstrate durable resistance, the disease reaction in the field trials should be evaluated for several crop years, considering the ideal age of the plants and the favorable climate conditions for the pathogen occurrence (30). These conditions were met in the present study, providing reliable data for breeders in the search for increasing resistance levels to orange rust. However, the presence of G1 marker in intermediate and susceptible cultivars, such as RB92579, RB855156, RB925211 and RB72454, also indicates that more studies are necessary to elucidate the inheritance of the resistance gene linked to G1 and to understand which cellular mechanisms are responsible for decreasing the disease severity. Furthermore, the half-sib cultivars RB855536, RB835054 and RB855156 suggest that more than one copy of the resistance gene linked to G1 marker may be needed to increase the resistance levels to orange rust. Finally, investigation to find new sources of resistance to orange rust is fundamental, since resistant cultivars without the resistance gene linked to G1 marker, as indicated for SP80-1842, RB975242, RB975201, RB835486, RB985476 and RB975952, may be very useful for breeding programs in the maintenance of horizontal resistance.

This study is the first to report the use of G1 molecular marker in Brazilian sugarcane germplasm, showing its capacity to predict the resistant phenotype and potential to be used in MAS of orange rust resistance in sugarcane. The resistance gene linked to G1 marker was effective in decreasing the disease severity and was present in important cultivars grown in Brazil. The G1 marker is a valuable tool for breeding programs in the search for increasing resistance levels to sugarcane orange rust.

\section{ACKNOWLEDGMENTS}

We gratefully thank Prof. Jianping Wang, Agronomy Department at Florida University (USA), for her comments on the manuscript. IF received a scientific initiation fellowship from $\mathrm{CNPq}$ (Brazilian National Council for Scientific and Technological Development), granted by the Institutional Program of Scientific Initiation Scholarships - Federal University of São Carlos (UFSCar).

\section{REFERENCES}

1. Braithwaite, K.S.; Croft, B.J.; Magarey, R.C.; Scharaschkin, T. Phylogenetic placement of the sugarcane orange rust pathogen Puccinia kuehnii a historical and regional context. Australasian Plant Pathology, Calyton, v.38, p.380-388, 2009.

2. Magarey, R.C.; Croft, B.; Willcox. T.G. An epidemic of orange rust on sugarcane in Australia. Proceedings Australian Society of Sugarcane Technologists, Balina, v.24, p.410-416, 2001.

3. Magarey, R.C.; Bull, J.I.; Neilsen, W.A. Yield losses caused by several endemic diseases in Queensland. Proceedings Australian Society of Sugarcane Technologists, Balina, v.25, p.8, 2003.

4. Magarey, R.C.; Royal, A.; Williams, D.J.; Bull, J.I. A brief history of disease epidemics in Queensland and of some economic outcomes. Proceedings Australian Society of Sugarcane Technologists, Balina, v.33, p.1-12, 2011.

5. Comstock, J.C.; Sood, S.G.; Glynn, N.C.; Shine, J.M. Jr.; McKemy, J.M.; Castlebury, L.A. First report of Puccinia kuehnii, causal agent of orange rust of sugarcane, in the United States and Western Hemisphere. Plant Disease, St. Paul, v.92, p.175, 2008.

6. Ovalle, W.; Comstock, J.C.; Glynn, N.C.; Castlebury, L.A. First report of Puccinia kuehnii, causal agent of orange rust of sugarcane, in Guatemala. Plant Disease, St. Paul, v.92, p.973, 2008.

7. Flores, R.C.; Loyo, J.R.; Ojeda, R.A.; Rangel, O.C.A. First Report of Orange Rust of Sugarcane Caused by Puccinia kuehnii in Mexico, El Salvador, and Panama. Plant Disease, St. Paul, v.93, p.1347, 2009.

8. Chavarría, E.; Subiros, F.; Vega, J.; Ralda, G.; Glynn, N.C.; Comstock, J.C.; Castlebury, L.A. First report of orange rust caused by Puccinia kuehnii in Costa Rica and Nicaragua. Plant Disease, St. Paul, v.93, p.325, 2009.

9. Cadavid, M.; Angel, J.C.; Victoria, J.I. First Report of Orange Rust of Sugarcane Caused by Puccinia kuehnii in Colombia. Plant Disease, St. Paul, v.96, p.143, 2012.

10. Garcés, F.F.; Fiallos, F.F.; Silva, E.; Martinez, F.; Aime, M.C.; Comstock, J.C.; Glynn, N.C.; Castlebury, L.A. First report of orange rust of sugarcane caused by Puccinia kuehnii in Ecuador. Plant Disease, St. Paul, v.98, p.842, 2014. 
11. Barbasso, D.; Jordão, H.; Maccheroni, W.; Boldini, J.; Bressiani, J.; Sanguino, A. First report of Puccinia kuehnii, causal agent of orange rust of sugarcane, in Brazil. Plant Disease, St. Paul, v.94, p.1170, 2010.

12. FAO. FAOSTAT. Production statistics. Roma: FAO. Available in: <http:// www.fao.org/faostat/en/\#data/QC/visualize>. Access in: 16 Jan. 2019.

13. Cana-de-açúcar, Safra, 2018-2019. Segundo Levantamento, Agosto de 2018. Available at: <https:/www.conab.gov.br/info-agro/safras/cana>. Access on 12 Sept 2018.

14. Magarey, R.C. Orange rust disease of sugarcane. In: Rott, P.; Bailey, R.A.; Comstock, J.C.; Croft, B.J.; Saumtally, A.S. (Ed.) A guide to sugarcane diseases. Montpellier: CIRAD, 2000. p.121-125.

15. Rott, P.; Sood, S.; Comstock, J.C.; Raid, R.N.; Glynn, N.C.; Gilbert, R.A.; Sandhu, H.S. Sugarcane Orange Rust. Florida Sugarcane Handbook (UF/ IFAS), Gainesville, v.1, p.1, 2014.

16. Magarey, R.C.; Bull, J.I.; Neilsen, W.A.; Camilleri, J.R.; Magnanini, A.J. Relating cultivar resistance to sugarcane yield using breeding selection trial analyses; orange rust and yellow spot. Australian Journal of Experimental Agriculture, Collingwood, v.44, p.1057-1064, 2004.

17. Zhao, D.; Glynn, N.C.; Glaz, B.; Comstock, J.C.; Sood, S. Orange rust effects on leaf photosynthesis and related characters of sugarcane. Plant Disease, St. Paul, v.95, p.640-647, 2011.

18. Araújo, K.L.; Canteri, M.G.; Gilio, T.A.S.; Neubauer, R.A.; Sanches, P.B.; Sumida, C.H.; Giglioti, E.A. Resistência genotípica e monitoramento da favorabilidade para ocorrência da ferrugem alaranjada da cana-de-açúcar. Summa Phytopathologica, Botucatu, v.39, p.271-275, 2013.

19. Chapola, R.G.; Hoffmann, H.P.; Massola, N.S. Reaction of sugarcane cultivars to orange rust (Puccinia kuehnii) and methods for rapid identification of resistant genotypes. Tropical Plant Pathology, Brasília, v.41, p.139-146, 2016.

20. Moreira, A.S.; Nogueira, Junior A.F.; Gonçalves, C.R.N.B.; Souza, N.A.; Bergamin Filho, A. Pathogenic and molecular comparison of Puccinia kuehnii isolates and reactions of sugarcane cultivars to orange rust. Plant Pathology, Henwick Grove, v.67, p.1687-1696, 2018.

21. Tai, P.Y.P.; Miller, J.D.; Dean, J.L. Inheritance of resistance to rust in sugarcane. Field Crops Research, [S.I.], v.4, p.261-268, 1981.
22. Amorim, L.; Bergamin Filho, A.; Cardoso, C.; Moraes, V.A.; Fernandes, C.R. Metodologia de avaliação da ferrugem da cana de açúcar (Puccinia melanocephala). Boletim Técnico Copersucar, Piracicaba, v.39, p.13-16, 1987.

23. Sood, S.G.; Comstock, J.C.; Glynn, N.C. Leaf whorl inoculation method for screening sugarcane rust resistance. Plant Disease, St. Paul, v.93, p.1335-1340, 2009.

24. Klosowski, A.C.; Bespalhok Filho, J.C.; Ruaro, L.; May de Mio, L.L. Proposta e validação de escala para a ferrugem alaranjada da cana-de-açúcar. Tropical Plant Pathology, Brasília, v.38, p.166-171, 2013.

25. Klosowski, A.C.; Bespalhok Filho, J.C.; Ruaro, L.; May de Mio, L.L. Inheritance of Resistance to Orange Rust (Puccinia kuehnii) in Sugarcane Families from Crosses Between Parents with Different Orange Rust Reactions. Sugar Tech, New Delhi, v.15, p.379-383, 2013.

26. Yang, X.; Islam, M.S.; Sood, S.; Maya, S.; Hanson, E.A.; Comstock, J.C.; Wang, J. Identifying Quantitative Trait Loci (QTLs) and Developing Diagnostic Markers Linked to Orange Rust Resistance in Sugarcane (Saccharum spp.). Frontiers in Plant Science, Lausanne, v.9, p.1-2. 2018.

27. Parco, A.S.; Avellaneda, M.C.; Hale, A.H.; Hoy, J.W.; Kimbeng, C.A.; Pontif M.J.; Gravois, K.A.; Baisakh, N. Frequency and distribution of the brown rust resistance gene Brul and implications for the Louisiana sugarcane breeding programme. Plant Breeding, Bonn, p.1-6, 2014.

28. Barreto, F.Z.; Balsalobre, T.W.A.; Chapola, R.G.; Hoffmann, H.P.; Carneiro M.S. Validation of molecular markers associated with brown rust resistance in sugarcane. Summa Phytopathologica, Botucatu, v.43, p.36-40, 2017.

29. Rede Interuniversitária para o Desenvolvimento do Setor Sucroenergético. Censo varietal. Available at: https://www.ridesa.com.br/censo-varietal. Access on: 16 Jan 2019.

30. Sentelhas, P.C.; dos Santos, D.L.; Monteiro, L.A.; Soares-Colletti, A.R.; Pallone Filho, W.J.; Donzelli, J.L.; Arrigoni, E.B. Agro-climatic favorability zones for sugarcane orange rust as a tool for cultivar choice and disease management. Crop Protection, Lincoln, v.84, p.88-97, 2016.

31. Al-Janabi, S.; Forget, L.; Dookun, A. An improved and rapid protocol for the isolation of polysaccharide-and polyphenol-free sugarcane DNA. Plant Molecular Biology Reporter, New York, v.17, p.281-281, 1999.

32. Bordonal, R.D.O.; Carvalho, J.L.N.; Lal, R.; de Figueiredo, E.B.; de Oliveira, B.G.; La Scala, N. Sustainability of sugarcane production in Brazil: a review. Agronomy for Sustainable Development, Montpellier, v.38, p.13, 2018. 